Article

\title{
Fe, N, S-doped porous carbon as oxygen reduction reaction catalyst in acidic medium with high activity and durability synthesized using $\mathrm{CaCl}_{2}$ as template
}

\author{
Chi Chen a,b, Zhiyou Zhou b, Yucheng Wang b, Xue Zhang b, Xiaodong Yang b, Xinsheng Zhang a,\#, \\ Shigang Sun a,b,* \\ a State Key Laboratory of Chemical Engineering, College of Chemical Engineering, East China University of Science and Technology, Shanghai 200237, \\ China \\ b State Key Laboratory of Physical Chemistry of Solid Surfaces, Collaborative Innovation Center of Chemistry for Energy Materials, College of Chemistry \\ and Chemical Engineering, Xiamen University, Xiamen 361005, Fujian, China
}

\section{A R T I C L E I N F O}

\section{Article history:}

Received 17 February 2017

Accepted 7 March 2017

Published 5 April 2017

\section{Keywords:}

Non-precious metal catalyst

Oxygen reduction reaction

Proton exchange membrane fuel cell

Fe, N, S-doped porous carbon

Melamine formaldehyde resin

\begin{abstract}
A B S T R A C T
Proton exchange membrane fuel cells suffer from the sluggish kinetics of the oxygen reduction reaction (ORR) and the high cost of Pt catalysts. In the present work, a high-performance ORR catalyst based on Fe, N, S-doped porous carbon (FeNS-PC) was synthesized using melamine formaldehyde resin as $\mathrm{C}$ and $\mathrm{N}$ precursors, $\mathrm{Fe}(\mathrm{SCN})_{3}$ as $\mathrm{Fe}$ and $\mathrm{S}$ precursors, and $\mathrm{CaCl}_{2}$ as a template via a two-step heat treatment without a harsh template removal step. The results show that the catalyst treated at $900{ }^{\circ} \mathrm{C}$ (FeNS-PC-900) had a high surface area of $775 \mathrm{~m}^{2} / \mathrm{g}$, a high mass activity of $10.2 \mathrm{~A} / \mathrm{g}$ in an acidic medium, and excellent durability; the half-wave potential decreased by only $20 \mathrm{mV}$ after 10000 potential cycles. The FeNS-PC-900 catalyst was used as the cathode in a proton exchange membrane fuel cell and delivered a peak power density of $0.49 \mathrm{~W} / \mathrm{cm}^{2}$. FeNS-PC-900 therefore has good potential for use in practical applications.
\end{abstract}

(C) 2017, Dalian Institute of Chemical Physics, Chinese Academy of Sciences. Published by Elsevier B.V. All rights reserved.

\section{Introduction}

Proton exchange membrane fuel cells (PEMFCs) are sustainable and highly efficient energy-conversion devices that convert chemical energy directly to electricity [1]. The sluggish kinetics of the oxygen reduction reaction (ORR) on the cathode of a PEMFC significantly reduces the PEMFC performance, and highly active ORR electrocatalysts such as Pt and its alloys are usually needed [2,3]. However, the high price and scarcity of Pt are an obstacle to large-scale applications of PEMFCs [4]. The development of high-performance and low-cost non-precious-metal catalysts, especially $\mathrm{Fe} / \mathrm{N} / \mathrm{C}$-based materials, as alternatives has therefore attracted extensive interest [5].

$\mathrm{Fe} / \mathrm{N} / \mathrm{C}$-based materials are usually prepared by pyrolyzing a mixture of $\mathrm{Fe}, \mathrm{N}$, and $\mathrm{C}$ precursors. These materials have good catalytic activities and excellent tolerances toward fuel crossover [6-8]. Although the ORR activities of Fe/N/C catalysts in alkaline media are comparable to those of state-of-the-art Pt/C catalysts, their ORR activities in acidic media are much lower, and far from satisfactory [9-11]. Previous studies have shown

\footnotetext{
* Corresponding author. Tel: +86-592-2180181; E-mail: sgsun@xmu.edu.cn

\# Corresponding author. Tel: +86-21-64253469; E-mail: xszhang@ecust.edu.cn

This work was supported by the National Basic Research Program of China (973 Program, 2015CB932303) and the National Natural Science Foundation of China $(21373175,21621091)$.

DOI: 10.1016/S1872-2067(17)62807-9 | http://www.sciencedirect.com/science/journal/18722067 | Chin. J. Catal., Vol. 38, No. 4, April 2017
} 
that additional doping of $\mathrm{Fe} / \mathrm{N} / \mathrm{C}$ catalysts with S significantly improves the ORR activity in acidic media [12]. More importantly, a high ORR activity depends on the single-site turnover and the active site density. The carbon supports in precursors are generally unable to catalyze the ORR, and probably reduce the active site density in the final product [13]. Direct carbonization of precursors leads to collapse of the carbon skeleton and formation of dense carbon materials. Colloidal or mesoporous silica is frequently used as a hard template to increase the catalyst surface area and porosity to provide internal active sites and a porous nanostructure to facilitate mass transport [14,15]. Feng and coworkers [16] used silica nanoparticles, ordered mesoporous silica SBA-15, and montmorillonite as templates to prepare various mesoporous structures. Their studies showed that the well-defined porous structure and high Brunauer-Emmett-Teller (BET) surface area generated by silica nanoparticles greatly improved the ORR performance. However, the removal of a silica template is normally tedious and requires the use of extremely corrosive and toxic reagents such as HF. In addition, the corrosive etching procedure can damage the newly formed ORR active sites. Although catalyst preparation methods have been widely studied, the use of $\mathrm{Fe} / \mathrm{N} / \mathrm{C}$ catalysts in fuel cells is still a challenge, especially in terms of durability at high voltages $[5,17]$.

In this study, we developed a novel Fe, N, S-doped porous carbon (FeNS-PC) with high catalytic activity in the ORR in an acidic medium. Melamine formaldehyde (MF) resin, which has a high $\mathrm{N}$ content (45 wt\%) and good thermostability, was selected as the $\mathrm{C}$ and $\mathrm{N}$ precursors. $\mathrm{Fe}(\mathrm{SCN})_{3}$ was used as the $\mathrm{Fe}$ source because it can provide both Fe and S. More importantly, $\mathrm{CaCl}_{2}$, which can be easily removed under mild conditions, was used as a template to create a porous structure. The MF resin can only be converted to porous carbon at temperatures higher than $900{ }^{\circ} \mathrm{C}$ under Fe catalysis. The catalyst heat treated at this temperature (FeNS-PC-900) had a high BET surface area and porosity, and showed high ORR activity in an acidic medium, as well as superior durability and methanol tolerance. The high performance of a PEMFC with FeNS-PC-900 as the cathode shows that the FeNS-PC-900 catalyst has good potential applications.

\section{Experimental}

\subsection{Synthesis of Fe, $N$, S-doped porous carbon}

Scheme 1 shows the synthesis of FeNS-PC. The first step was polymerization of MF resin [18]. In brief, melamine (1.97 g, $15.6 \mathrm{mmol}$ ) and formaldehyde aqueous solution $(37 \%, 3 \mathrm{~mL})$ were dispersed in deionized water $(30 \mathrm{~mL})$ by magnetic stirring. The temperature was controlled at $70{ }^{\circ} \mathrm{C}$. Then $0.1 \mathrm{~mol} / \mathrm{L}$ $\mathrm{NaOH}(1 \mathrm{~mL})$ was added to the mixture to adjust the $\mathrm{pH}$ to 8-9. The melamine powder dissolved in a few minutes and the solution became transparent. After stirring for $1 \mathrm{~h}$, the $\mathrm{pH}$ was adjusted to $5-6$ by addition of $1 \mathrm{~mol} / \mathrm{L} \mathrm{HCl}(0.2 \mathrm{~mL})$ to accelerate resin polymerization. $\mathrm{CaCl}_{2}(2.22 \mathrm{~g}, 20 \mathrm{mmol})$ and $\mathrm{KSCN}(2.92$ $\mathrm{g}, 30 \mathrm{mmol}$ ) were added to the mixture, followed by dropwise addition of $\mathrm{FeCl}_{3}$ aqueous solution ( $1 \mathrm{~mol} / \mathrm{L}, 10 \mathrm{mmol}, 10 \mathrm{~mL}$ ) under vigorous stirring. The temperature was increased to 85 ${ }^{\circ} \mathrm{C}$ and maintained for $24 \mathrm{~h}$. The solvent was evaporated from the mixture at $85{ }^{\circ} \mathrm{C}$ in air, and the residue was thoroughly dried at $80^{\circ} \mathrm{C}$ in a vacuum oven overnight. After thorough drying of the precursors, the $\mathrm{CaCl}_{2}$ particles act as buffers to prevent thermo-crosslinking of the MF resin, and as a template to prevent collapse of the carbon skeleton. Unlike silica templates, $\mathrm{CaCl}_{2}$ can be easily removed by acid leaching without using highly toxic and corrosive conditions.

The obtained monoliths ( $3 \mathrm{~g}$ ) were ground to fine powders, followed by heat treatment at $800-1000{ }^{\circ} \mathrm{C}$ in $\mathrm{Ar}$ for $1 \mathrm{~h}$. The sample was subjected to acid leaching in $1 \mathrm{~mol} / \mathrm{L} \mathrm{HCl}$ at $80{ }^{\circ} \mathrm{C}$ for $7 \mathrm{~h}$ to remove the template and inactive species by etching. The sample was separated by centrifugation and rinsed three times. Finally, the catalyst was subjected to a second heat treatment at the same temperature for $3 \mathrm{~h}$; the product was denoted by FeNS-PC- $T$, where $T$ is the heat-treatment temperature $\left({ }^{\circ} \mathrm{C}\right)$.

\subsection{Characterization}

The sample morphology was investigated using transmission electron microscopy (TEM; JEM-1400) at $100 \mathrm{kV}$. Annular dark-field scanning transmission electron microscopy

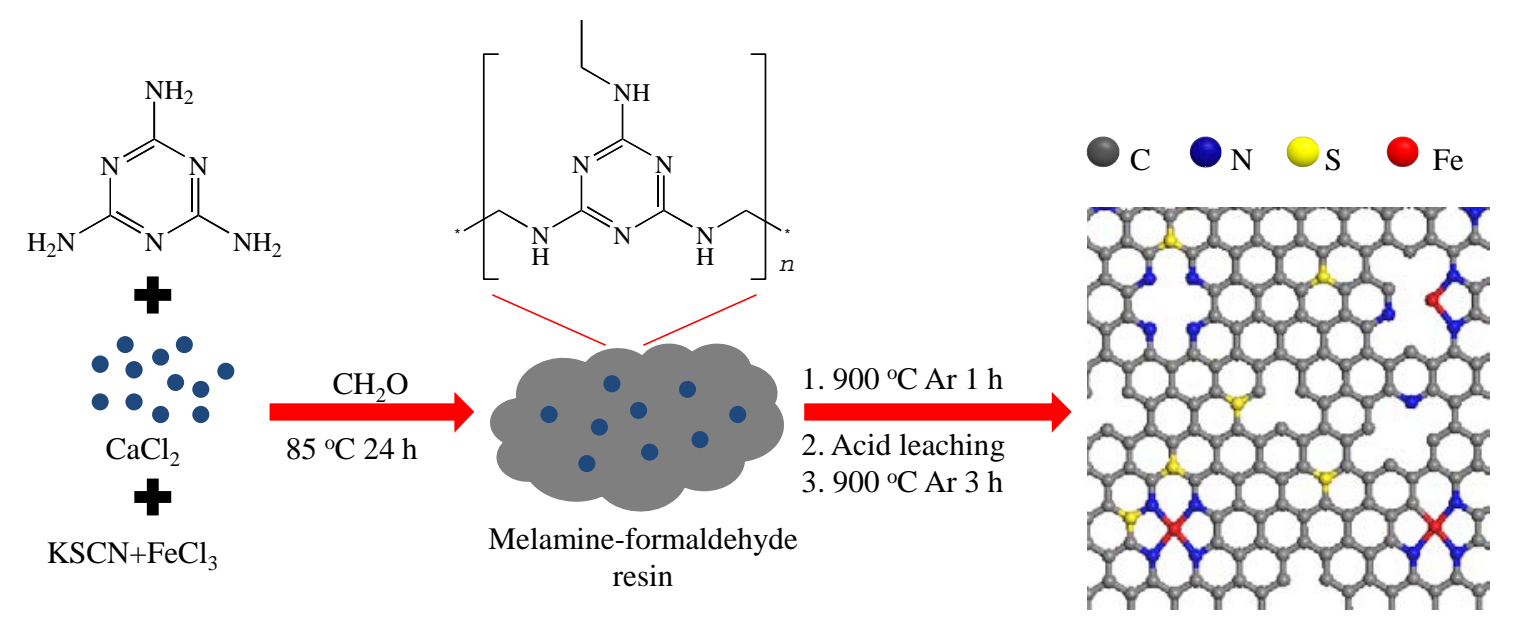

Scheme 1. Synthesis of Fe, N, S-doped porous carbon. 
(ADF-STEM) and energy-dispersive X-ray spectroscopy (EDS) mapping were performed using a Philips-FEI TECNAI F20 instrument at $200 \mathrm{kV}$. The BET surface area was determined using a Micromeritics TriStar II 3020 instrument. X-ray diffraction (XRD) was performed using a Rigaku Ultima IV diffractometer with $\mathrm{Cu} K_{\alpha}$ radiation. X-ray photoelectron spectroscopy (XPS; Qtac-100 LEISS-XPS) was used to investigate the elemental compositions and chemical states.

All electrocatalytic properties were investigated using a rotating ring-disk electrode (RRDE) system (Pine Inc.) connected to a CHI-760D bipotentiostat. The working electrode was prepared by dropping catalyst ink onto a polished glassy carbon electrode ( $\phi=5.61 \mathrm{~mm})$ and drying under an infrared lamp in air, to give a loading of $0.6 \mathrm{mg} / \mathrm{cm}^{2}$. A laboratory-made reversible hydrogen electrode and a graphite plate were used as the reference electrode and counter electrode, respectively. The rotational speed was fixed at $900 \mathrm{r} / \mathrm{min}$ and the potential scan rate was $10 \mathrm{mV} / \mathrm{s}$. The potential of the Pt ring electrode was kept at $1.3 \mathrm{~V}$ to oxidize $\mathrm{H}_{2} \mathrm{O}_{2}$. The electrolytes were $0.1 \mathrm{~mol} / \mathrm{L}$ $\mathrm{H}_{2} \mathrm{SO}_{4}$ for non-precious-metal catalysts, and $0.1 \mathrm{~mol} / \mathrm{L} \mathrm{HClO}_{4}$ for a Pt/C (20 wt\%) catalyst. The Pt/C loading was $0.1 \mathrm{mg} / \mathrm{cm}^{2}$.

The kinetic current of the catalyst was calculated using the Koutecky-Levich equation to correct the mass transfer:

$$
1 / i=1 / i_{\mathrm{L}}+1 / i_{\mathrm{k}}
$$

where $i, i_{\mathrm{L}}$, and $i_{\mathrm{k}}$ are the measured current, the diffusion-limited current, and the kinetic current, respectively. The mass activity $(j \mathrm{~m})$ was obtained by normalizing $i_{\mathrm{k}}$ with the catalyst loading.

The $\mathrm{H}_{2} \mathrm{O}_{2}$ yield was calculated from the oxygen reduction current $\left(I_{D}\right)$ and the $\mathrm{H}_{2} \mathrm{O}_{2}$ oxidation current $\left(I_{R}\right)$ according to the following equation:

$$
\mathrm{H}_{2} \mathrm{O}_{2} \text { yield }=200 I_{\mathrm{R}} /\left(N_{0} I_{\mathrm{D}}+I_{\mathrm{R}}\right)
$$

where $N_{0}=0.386 \pm 0.002$ is the Pt ring collection efficiency, $I_{D}$ is the disk current, and $I_{\mathrm{R}}$ is the ring current.

\subsection{PEMFC test}

The synthesized catalyst was used as the cathode in a PEMFC. A typical catalyst ink was prepared by dispersing FeNS-PC-T $(26 \mathrm{mg})$ and $5 \mathrm{wt} \%$ Nafion solution $(600 \mu \mathrm{L})$ in deionized water $(1 \mathrm{~mL})$ by sonication for $1 \mathrm{~h}$. The ink was directly coated on hydrophobic treated carbon paper at a loading of 4 $\mathrm{mg} / \mathrm{cm}^{2}$. The Nafion content of the catalyst layer was about 50 wt\%. For the anode, the catalyst was a commercial Pt/C (40 $w t \%)$ catalyst with a loading of $0.4 \mathrm{mg} \mathrm{pt} / \mathrm{cm}^{2}$. Membrane electrode assemblies (MEAs) were fabricated by hot-pressing the anode, cathode, and an NRE 211 Nafion membrane at $3 \mathrm{MPa}$ for $135 \mathrm{~s}$. The performance of the fuel cell was assessed using a Model 850e fuel cell test system (Scribner Associates Inc.) operated at $80{ }^{\circ} \mathrm{C}$. The $\mathrm{H}_{2}$ and $\mathrm{O}_{2}$ flow rates were $0.3 \mathrm{~L} / \mathrm{min}$ at $100 \%$ relative humidity and the back pressure was 1 bar.

\section{Results and discussion}

The morphologies and structures of the FeNS-PC materials greatly depended on the heat-treatment temperature because no additional carbon supports were used. Fig. 1(a)-(e) shows typical TEM images of FeNS-PC-800, FeNS-PC-900, and FeNS-PC-1000. The images show that the MF resin was converted to porous carbon at high temperatures by Fe catalysis [19]. Fe-containing nanoparticles can be seen in FeNS-PC-800. FeNS-PC-900 and FeNS-PC-1000 were free of crystallized nanoparticles. Irregular porous structures can be clearly observed in the enlarged TEM images of FeNS-PC-900 and FeNS-PC-1000 (Fig. 1(c) and (e), respectively). A porous structure facilitates mass transfer and therefore improves the activity. We also
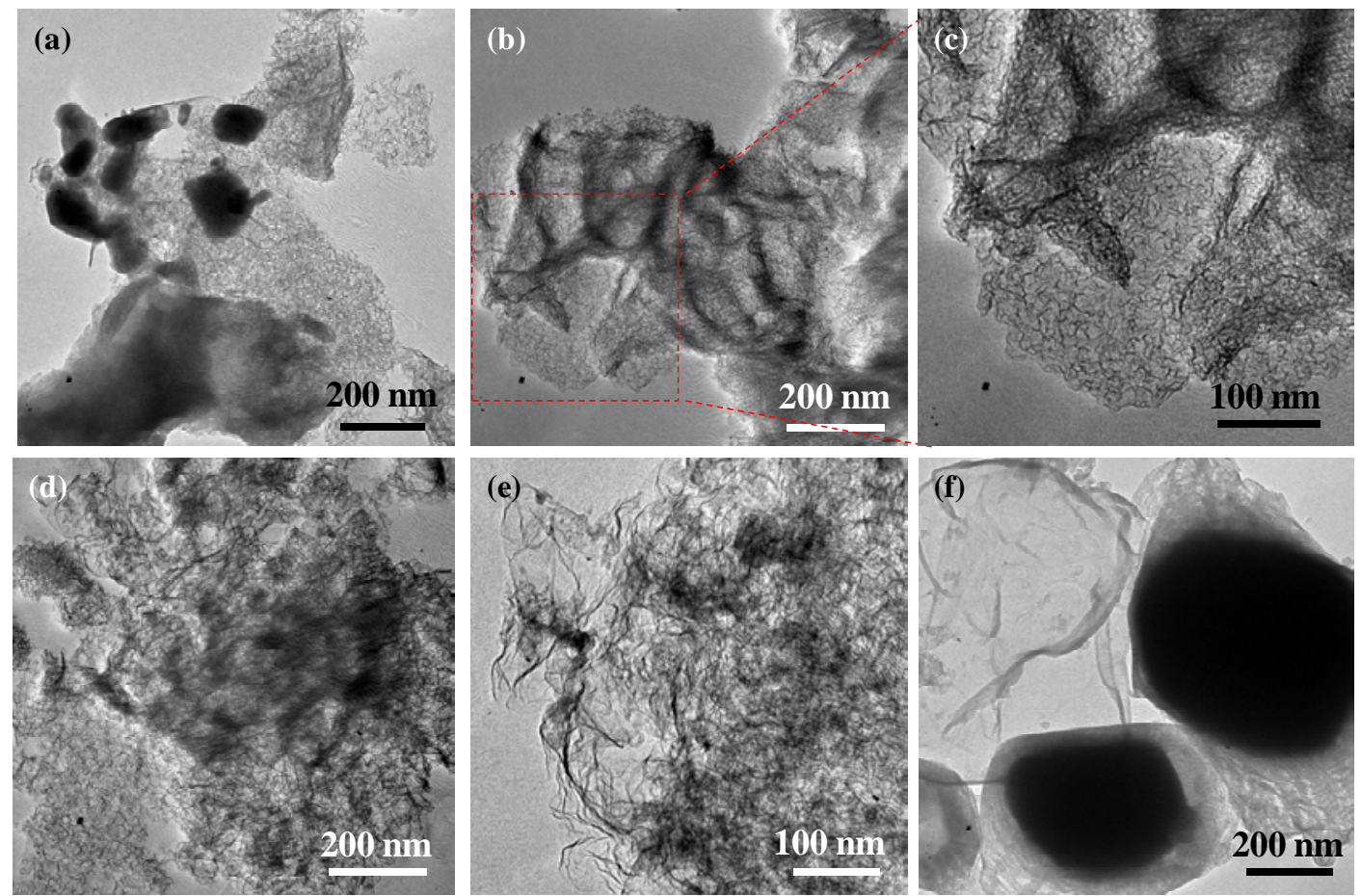

Fig. 1. TEM images of FeNS-PC-800 (a), FeNS-PC-900 (b, c), FeNS-PC-1000 (d, e), and sample without added $\mathrm{CaCl}_{2}$ (f). 
synthesized a sample by heat treatment at $900{ }^{\circ} \mathrm{C}$ but without addition of $\mathrm{CaCl}_{2}$ to investigate the effects of using $\mathrm{CaCl}_{2}$ as a template. Fig. 1(f) shows that large Fe-containing nanoparticles with thick carbon shells were formed instead of porous carbon, which would not give a high surface area and good ORR catalytic activity. This confirms the important role of $\mathrm{CaCl}_{2}$ in creating a porous structure. The mechanism of porous structure formation by $\mathrm{CaCl}_{2}$ may be as follows. $\mathrm{CaCl}_{2}$ dissolved in the aqueous reaction mixture during polymerization of the $\mathrm{MF}$ resin, along with $\mathrm{KSCN}$ and $\mathrm{FeCl}_{3}$. After thorough drying of the precursors, the recrystallized $\mathrm{CaCl}_{2}$ nanoparticles were dispersed uniformly throughout the MF resin. The inert $\mathrm{CaCl}_{2}$ nanoparticles acted as a template and prevented thermo-crosslinking of the MF resin at high temperatures and collapse of the carbon skeleton. During acid leaching, the channels formed by the dissolution of $\mathrm{CaCl}_{2}$ particles also facilitated exposure of Fe-containing nanoparticles to the acid. Porous carbon was therefore obtained.

The textural properties of FeNS-PC-800, FeNS-PC-900, and FeNS-PC-1000 were investigated based on their $\mathrm{N}_{2}$ adsorption-desorption isotherms (Fig. 2(a)). The calculated BET surface areas of FeNS-PC-800, FeNS-PC-900, and FeNS-PC-1000 were 544,775 , and $848 \mathrm{~m}^{2} / \mathrm{g}$, respectively. The low BET surface area of FeNS-PC-800 can be attributed to the formation of Fe-containing nanoparticles. The difference between the surface areas of FeNS-PC-900 and FeNS-PC-1000 was small because of their similar morphologies and structures.

XRD was used to determine the crystal structures of FeNS-PC-800, FeNS-PC-900, and FeNS-PC-1000; the results are shown in Fig. 2(b). The XRD pattern of FeNS-PC-800 shows the presence of metallic Fe and FeS nanoparticles, which is consistent with the TEM results. These Fe-containing nanoparticles were probably covered by carbon shells and survived acid leaching. The broad peak at around $25.5^{\circ}$ indicates the co-existence of porous carbon. The FeNS-PC-900 and FeNS-PC-1000 show only two main peaks, at $2 \theta=25.5^{\circ}$ and $43^{\circ}$, originating from the (002) and (101) reflections, respectively, of graphene. The absence of peaks from $\mathrm{CaCl}_{2}$ in the XRD patterns indicates thorough removal of the $\mathrm{CaCl}_{2}$ template, in agreement with the TEM observations. EDS indicated that the atomic concentration of Ca in FeNS-PC-900 was only $0.17 \%$ (or

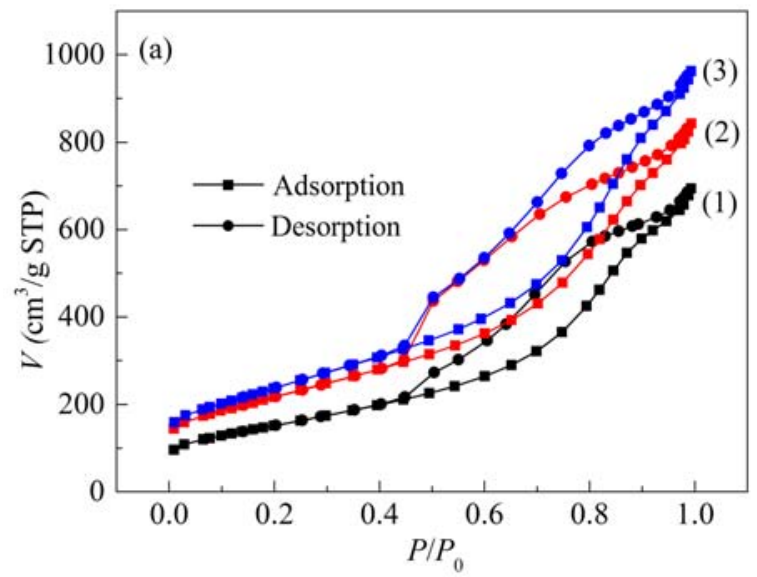

0.52 wt\%), confirming that the most of the $\mathrm{CaCl}_{2}$ template had been removed. The residual $\mathrm{CaCl}_{2}$ was probably located inside the porous carbon.

The elemental distribution in FeNS-PC-900 was determined using ADF-STEM mapping analysis. Fig. 3 shows that the major doping elements (C, N, O, S, and Fe) were all distributed uniformly on the porous carbon. Two factors could be responsible for this uniform distribution. (1) $\mathrm{Fe}(\mathrm{SCN})_{3}$, which was used as the $\mathrm{Fe}$ and $\mathrm{S}$ precursor, was well dispersed in the MF resin, which has a high $\mathrm{N}$ content of $45 \mathrm{wt} \%$. (2) Heteroatom doping was achieved simultaneously with porous carbon generation during heat treatment, leading to anchoring of the heteroatoms in the carbon matrix. All aggregated Fe-containing particles were removed thoroughly by acid leaching.

The elemental compositions and relevant chemical states of FeNS-PC- $T$ ( $T=800,900$, and 1000) were determined using XPS. The survey scan spectra show that the amount of doped $\mathrm{N}$ decreased significantly with increasing heat-treatment temperature; this might affect the ORR activity. Fig. 4(a) and Table 1 show that the main elements in FeNS-PC- $T$ were C, N, O, S, and $\mathrm{Fe}$. The atomic concentrations of these elements in FeNS-PC-900 were $84.81 \%, 6.62 \%, 7.45 \%, 0.82 \%$, and $0.31 \%$, respectively. The $\mathrm{N}$ and Fe contents of FeNS-PC-800 were $12.07 \%$ and $1.27 \%$, respectively, both higher than those of FeNS-PC-900. This can be attributed to less loss of $\mathrm{N}$ species by volatilization at low temperatures and the formation of Fe-containing nanoparticles. The N, S, and Fe species in FeNS-PC-1000 were almost completely volatilized and could hardly be detected in the final product. Although XPS showed that FeNS-PC-1000 had the highest 0 content, EDS suggested that the $\mathrm{O}$ atomic concentrations of FeNS-PC-800, FeNS-PC-900, and FeNS-PC-1000 were 7.38\%, 8.59\% and $6.50 \%$, respectively (Table 2). Oxygen-containing functional groups were probably introduced during post-treatment and when the catalysts were exposed to air. The $\mathrm{N}$ and $\mathrm{S}$ contents were also determined using EDS and CHNS elemental analysis. The results are consistent with those obtained using XPS (Tables 2 and 3). Inductively coupled plasma optical emission spectroscopy showed that the Fe contents of FeNS-PC-800, FeNS-PC-900, and FeNS-PC-1000 were 19.6, 3.4, and 2.8 wt\%, respectively. Fe doping is important in improving the ORR ac-

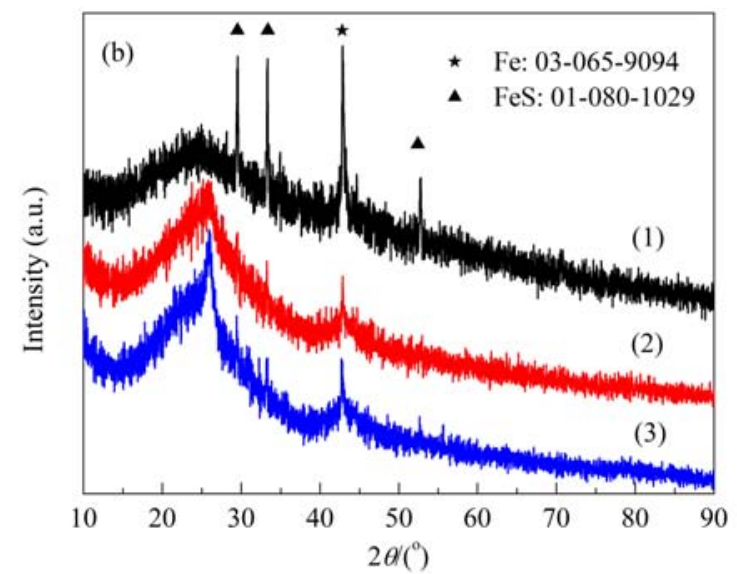

Fig. 2. $\mathrm{N}_{2}$ sorption isotherms (a) and XRD patterns (b) of FeNS-PC-800 (1), FeNS-PC-900 (2), and FeNS-PC-1000 (3). 

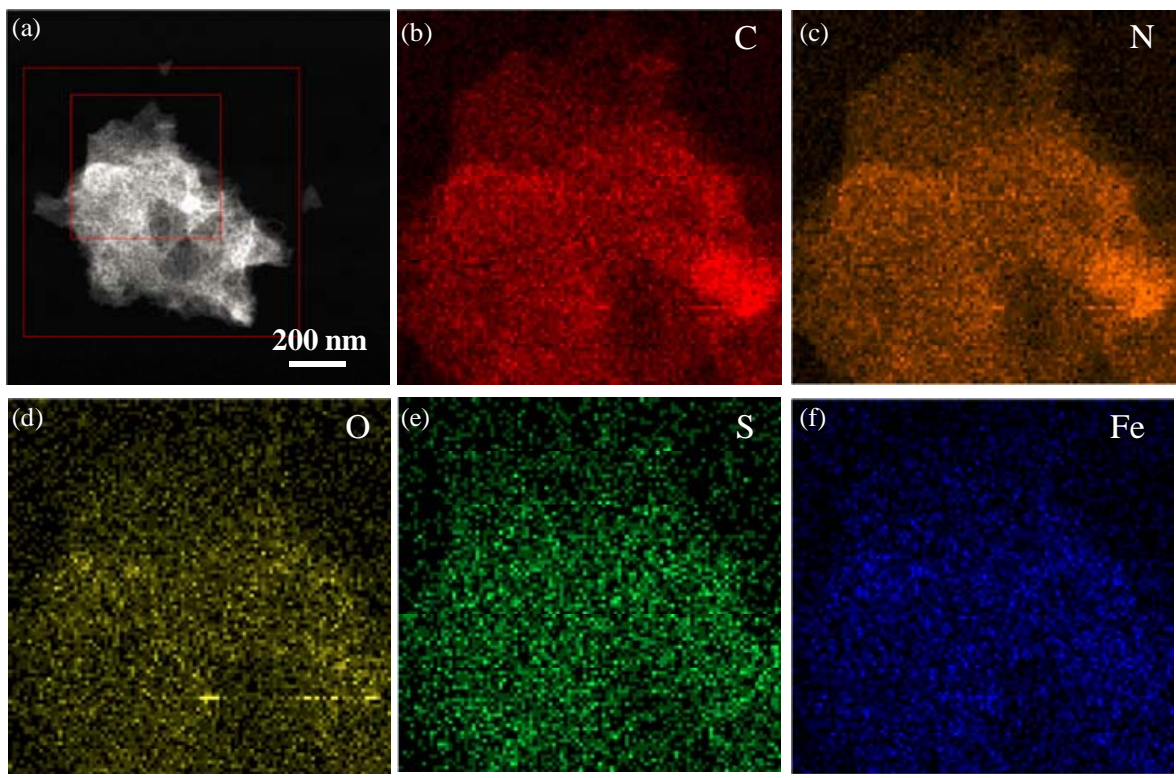

Fig. 3. ADF-STEM image (a) and EDS elemental mapping of C (b), N (c), O (d), S (e), and Fe (f) in FeNS-PC-900.
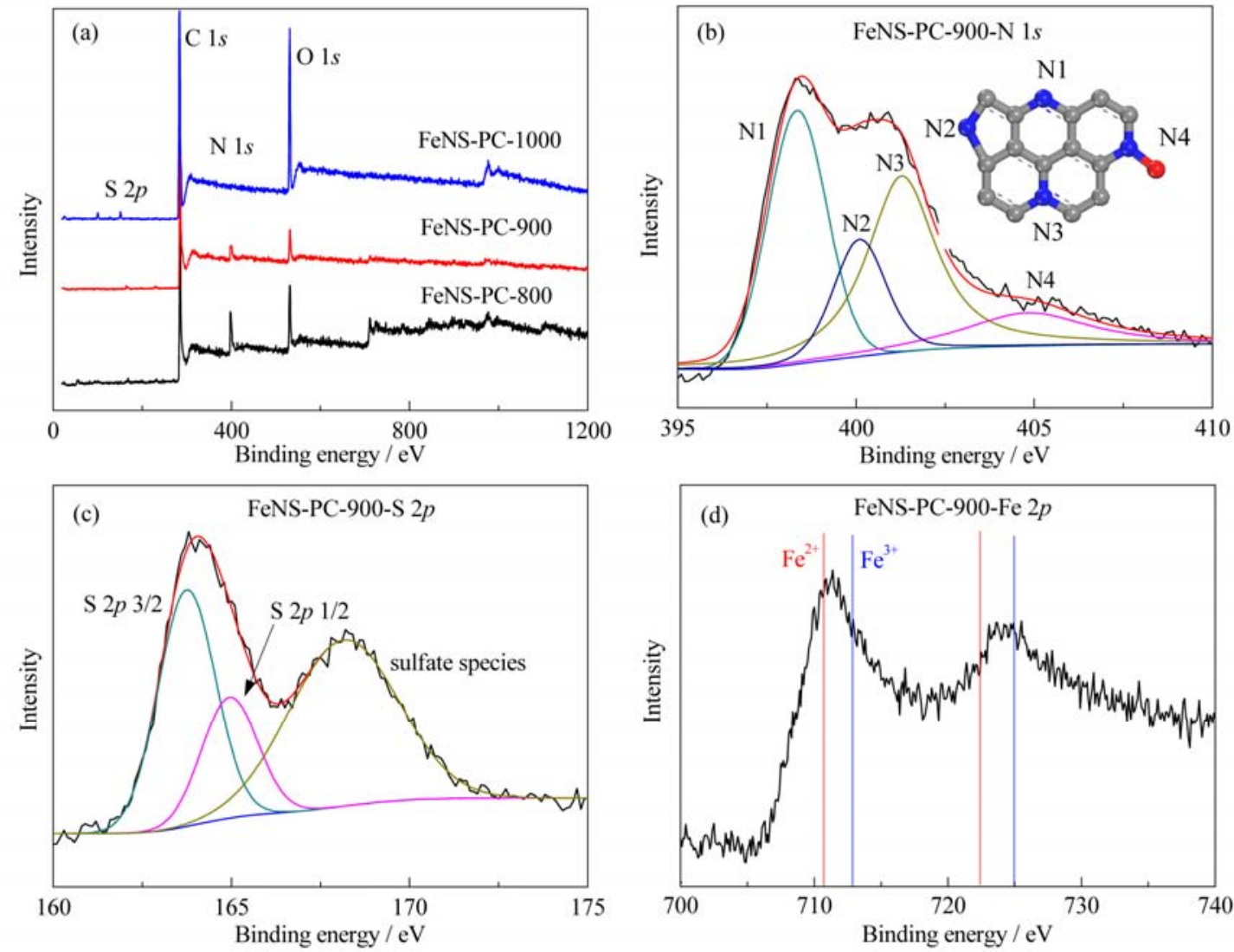

Fig. 4. (a) XPS survey spectra of FeNS-PC- $T$ ( $T=800,900,1000$ ); high-resolution $\mathrm{N} 1 s$ (b), $\mathrm{S} 2 p$ (c), and Fe $2 p$ (d) XPS spectra of FeNS-PC-900. Inset in (b) shows schematic diagram of different bonding configurations of N: N1, pyridinic; N2, pyrrolic; N3, graphitic; and N4, oxidized.

tivities of non-precious-metal catalysts, especially in acidic media.

The high-resolution N $1 s$ spectrum of FeNS-PC-900 (Fig. 4(b)) can be deconvoluted into four peaks, assigned to pyridinic N (N1), pyrrolic N (N2), graphitic N (N3), and oxidized N
(N4), with binding energies of 398.3, 400.1, 401.3, and 404.8 $\mathrm{eV}$, respectively [20]. The inset in Fig. 4(b) shows a schematic diagram of the different bonding configurations of N. However, only pyridinic $\mathrm{N}$ and graphitic $\mathrm{N}$ give good ORR catalytic activities [21]. The percentages of pyridinic $\mathrm{N}$ and graphitic $\mathrm{N}$ were 
Table 1

Element atomic concentrations of FeNS-PC- $T(T=800,900,1000)$ determined using XPS.

\begin{tabular}{lccccc}
\hline Catalyst & $\mathrm{C} / \%$ & $\mathrm{~N} / \%$ & $\mathrm{O} / \%$ & $\mathrm{~S} / \%$ & $\mathrm{Fe} / \%$ \\
\hline FeNS-PC-800 & 73.75 & 12.07 & 12.14 & 0.77 & 1.27 \\
FeNS-PC-900 & 84.81 & 6.62 & 7.45 & 0.82 & 0.31 \\
FeNS-PC-1000 & 73.91 & 0.50 & 25.39 & 0.15 & 0.06 \\
\hline
\end{tabular}

Table 2

EDS elemental analysis of atomic concentrations of FeNS-PC- $T(T=800$, $900,1000)$.

\begin{tabular}{lccccc}
\hline Catalyst & $\mathrm{C} / \%$ & $\mathrm{~N} / \%$ & $\mathrm{O} / \%$ & $\mathrm{~S} / \%$ & $\mathrm{Fe} / \%$ \\
\hline FeNS-PC-800 & 75.06 & 11.78 & 7.38 & 1.59 & 4.20 \\
FeNS-PC-900 & 84.33 & 6.03 & 8.59 & 0.62 & 0.43 \\
FeNS-PC-1000 & 91.38 & 0 & 6.50 & 0.50 & 1.62 \\
\hline
\end{tabular}

Table 3

CHNS elemental analysis of FeNS-PC- $T(T=800,900,1000)$.

\begin{tabular}{lcccc}
\hline Catalyst & $\mathrm{C} / \mathrm{wt} \%$ & $\mathrm{~N} / \mathrm{wt} \%$ & $\mathrm{~S} / \mathrm{wt} \%$ & $\mathrm{H} / \mathrm{wt} \%$ \\
\hline FeNS-PC-800 & 46.07 & 9.84 & 6.38 & 1.45 \\
FeNS-PC-900 & 68.02 & 3.27 & 2.78 & 1.56 \\
FeNS-PC-1000 & 80.68 & 0 & 2.05 & 1.31 \\
\hline
\end{tabular}

$33.9 \%$ and $37.8 \%$, respectively, calculated from the peak areas. The difference between the pyridinic $\mathrm{N}$ and $\mathrm{Fe}-\mathrm{N}$ species binding energies is small; therefore $\mathrm{Fe}-\mathrm{N}$ species may also contribute to the pyridinic $\mathrm{N}$ peak [16]. The high-resolution S $2 p$ spectrum of FeNS-PC-900 can be deconvoluted into three peaks, as shown in Fig. 4(c). The two peaks with binding energies of 163.8 and $165.0 \mathrm{eV}$ can be assigned to $\mathrm{S} 2 p_{3 / 2}$ and $\mathrm{S} 2 p_{1 / 2}$ of a thiophene-type $\mathrm{C}-\mathrm{S}-\mathrm{C}$ structure in the carbon matrix [22]. The peak at around $168.2 \mathrm{eV}$ can be ascribed to $-\mathrm{SO}_{x}$ species. According to previous reports [23], additional S doping would increase the number of structural defects and the electronic distribution because of the large size, electronegativity, and polarizability of the $\mathrm{S}$ atom. Fe, N, S co-doping has a synergistic effect and facilitates the ORR. Fig. 4(d) shows the high-resolution Fe $2 p$ spectrum of FeNS-PC-900; both $\mathrm{Fe}^{2+}$ and $\mathrm{Fe}^{3+}$ were present in the FeNS-PC-900 catalyst.

The electrocatalytic activities of FeNS-PC-800, FeNS-PC-900, and FeNS-PC-1000 in the ORR were examined in $\mathrm{O}_{2}$-saturated $0.1 \mathrm{~mol} / \mathrm{L} \mathrm{H}_{2} \mathrm{SO}_{4}$ solution using an RRDE system. For comparison, a commercial Pt/C (20 wt\%) catalyst was tested, but in $\mathrm{O}_{2}$-saturated $0.1 \mathrm{~mol} / \mathrm{L} \mathrm{HClO}_{4}$ solution to avoid specific adsorption of $\mathrm{SO}_{4}{ }^{2-}$ on the Pt surface. The ORR polarization curves for FeNS-PC-800, FeNS-PC-900, FeNS-PC-1000 (0.6 mg/ $\left.\mathrm{cm}^{2}\right)$, and $\mathrm{Pt} / \mathrm{C}\left(0.1 \mathrm{mg} / \mathrm{cm}^{2}\right)$ are shown in Fig. 5(a). It is apparent that the heat-treatment temperature plays an important role in inducing catalytic active sites. The MF resin was not completely converted to porous carbon at low temperatures $\left(800\right.$ or $\left.700{ }^{\circ} \mathrm{C}\right)$. However, a too-high temperature $\left(1000{ }^{\circ} \mathrm{C}\right)$ resulted in loss of all $\mathrm{N}$ species, as shown by elemental composition analysis. The optimal pyrolysis temperature was $900{ }^{\circ} \mathrm{C}$. The half-wave potentials $\left(E_{1 / 2}\right)$ of FeNS-PC-800, FeNS-PC-900, and FeNS-PC-1000 were $0.757,0.811$, and $0.723 \mathrm{~V}$, respectively, and the apparent current densities at $0.8 \mathrm{~V}$ were $1.16,2.47$, and $0.28 \mathrm{~mA} / \mathrm{cm}^{2}$, respectively. The kinetic current, which reflects the intrinsic activity, can be calculated using the Koutecky-Levich equation to correct the mass transfer effect. Normalizing the kinetic current with the catalyst loading gave a mass activity for FeNS-PC-900 at $0.8 \mathrm{~V}$ of $10.2 \mathrm{~A} / \mathrm{g}$, which is 3.6 times that of FeNS-PC-800 (2.8 A/g) and 20.4 times that of FeNS-PC-1000 (0.5 A/g). The $E_{1 / 2}$ of FeNS-PC-900 was only 78 $\mathrm{mV}$ lower than that of the $\mathrm{Pt} / \mathrm{C}$ catalyst, showing that FeNS-PC-900 is one of the best non-precious-metal catalysts reported to date [24-26]. The outstanding ORR activity of FeNS-PC-900 can be attributed to the high level of heteroatom doping and uniform atomic distribution of the $\mathrm{Fe}, \mathrm{N}$, and $\mathrm{S}$ dopants, which improve the intrinsic activity and active site density. The high surface area and porous structure provide channels to/from the internal active sites, facilitating the transport of reactants and products. In contrast, although FeNS-PC-800 had higher $\mathrm{Fe}, \mathrm{N}$, and $\mathrm{S}$ weight contents, TEM and XRD results showed that considerable portions of $\mathrm{Fe}$ and $\mathrm{S}$ were present as nanoparticles. Unlike dispersed $\mathrm{Fe}$ atoms, aggregated Fe-containing nanoparticles cannot catalyze the ORR; they decreased the surface area $\left(544 \mathrm{~m}^{2} / \mathrm{g}\right.$ for FeNS-PC-800 and 775 $\mathrm{m}^{2} / \mathrm{g}$ for FeNS-PC-900) and therefore decreased the ORR activity. For FeNS-PC-1000, which has a similar porous structure,
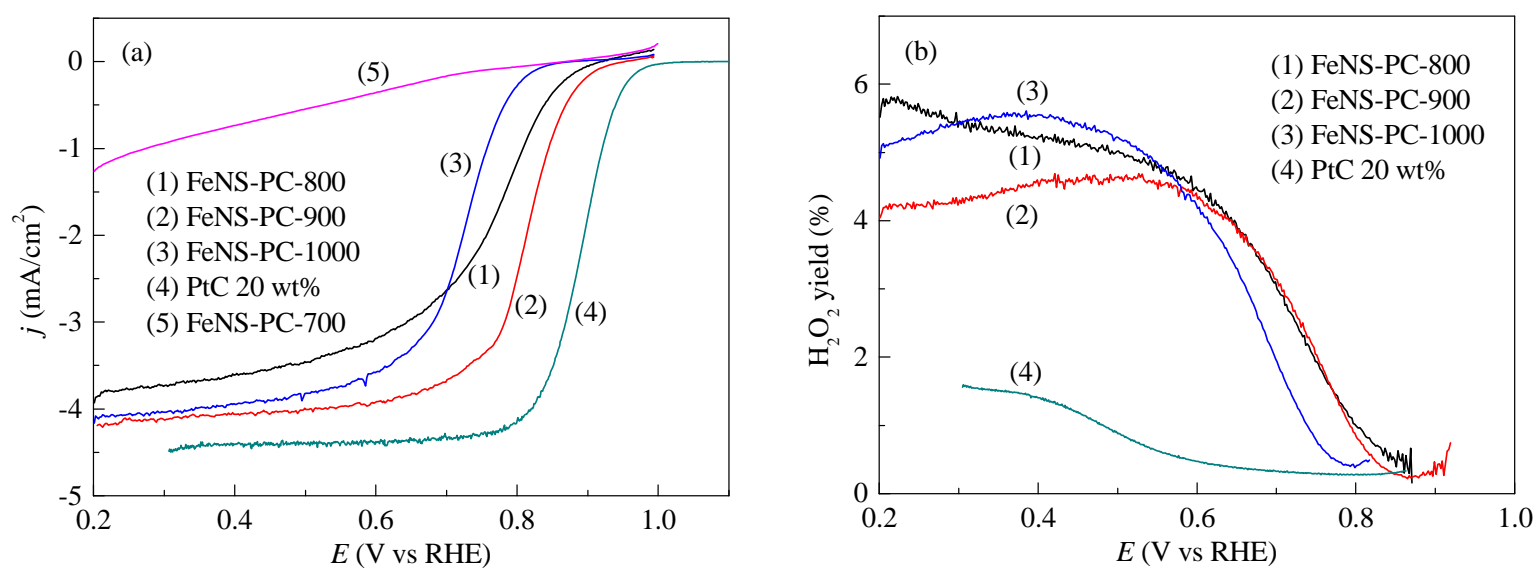

Fig. 5. ORR polarization curves (a) and $\mathrm{H}_{2} \mathrm{O}_{2}$ yields (b) for FeNS-PC- $T$ ( $\left.T=800,900,1000\right)$ and Pt/C (20 wt $\left.\%\right)$ catalyst. Catalyst loadings were 0.6 $\mathrm{mg} / \mathrm{cm}^{2}$ for FeNS-PC- $T$ and $0.1 \mathrm{mg} / \mathrm{cm}^{2}$ for Pt/C (or $20 \mu \mathrm{gPt}_{\mathrm{Pt}} / \mathrm{cm}^{2}$ ). The electrolytes were $\mathrm{O}_{2}$-saturated $0.1 \mathrm{~mol} / \mathrm{L} \mathrm{H} \mathrm{HO}_{4}$ for FeNS-PC- $T$ and $0.1 \mathrm{~mol} / \mathrm{L}$ $\mathrm{HClO}_{4}$ for Pt/C. Rotational speed: $900 \mathrm{r} / \mathrm{min}$; scan rate: $10 \mathrm{mV} / \mathrm{s}$. 
the poor ORR activity can be attributed to low heteroatom doping.

The $\mathrm{H}_{2} \mathrm{O}_{2}$ yields were evaluated by detecting the $\mathrm{H}_{2} \mathrm{O}_{2}$ oxidation current at the Pt ring electrode. Although their ORR activities differed greatly, there were only small differences among the $\mathrm{H}_{2} \mathrm{O}_{2}$ yields on FeNS-PC-800, FeNS-PC-900, and FeNS-PC-1000, as shown in Fig. 5(b). FeNS-PC-900 gave the lowest $\mathrm{H}_{2} \mathrm{O}_{2}$ yield; the maximum value was $4.6 \%$. Pt/C gave a much lower $\mathrm{H}_{2} \mathrm{O}_{2}$ yield, with a maximum value of $1.6 \%$. The average electron transfer number per reduced $\mathrm{O}_{2}$ molecule can be calculated as $n_{\mathrm{e}}=4-\left(\mathrm{H}_{2} \mathrm{O}_{2}\right.$ yield/50\%). The $n_{\mathrm{e}}$ for FeNS-PC-900 was greater than 3.91 across the whole potential range. At $0.8 \mathrm{~V}$, the $\mathrm{H}_{2} \mathrm{O}_{2}$ yield on FeNS-PC-900 was only $0.9 \%$ and the corresponding $n_{\mathrm{e}}$ was 3.98, indicating excellent four-electron pathway selectivity.

The electrochemical durability of FeNS-PC-900 was tested by performing an accelerated durability test (ADT) between 0.6 and $1.0 \mathrm{~V}$ in $\mathrm{O}_{2}$-saturated $0.1 \mathrm{~mol} / \mathrm{L} \mathrm{H}_{2} \mathrm{SO}_{4}$. The scan rate was $50 \mathrm{mV} / \mathrm{s}$. After 10000 potential cycles, the $E_{1 / 2}$ of FeNS-PC-900 had decreased by only $20 \mathrm{mV}$, as shown in Fig. 6(a). The apparent current densities at $0.8 \mathrm{~V}$ of FeNS-PC-900 before and after the ADT were 2.30 and $1.67 \mathrm{~mA} / \mathrm{cm}^{2}$, respectively. The corresponding mass activity decreased from 8.73 to $4.87 \mathrm{~A} / \mathrm{g}$, a loss of $44 \%$ of the initial activity. For the Pt/C catalyst, the $E_{1 / 2}$ decreased by $19 \mathrm{mV}$ under the same conditions (Fig. 6(b)). This result indicates that the stability of FeNS-PC-900 is similar to that of Pt/C under potential cycling conditions.
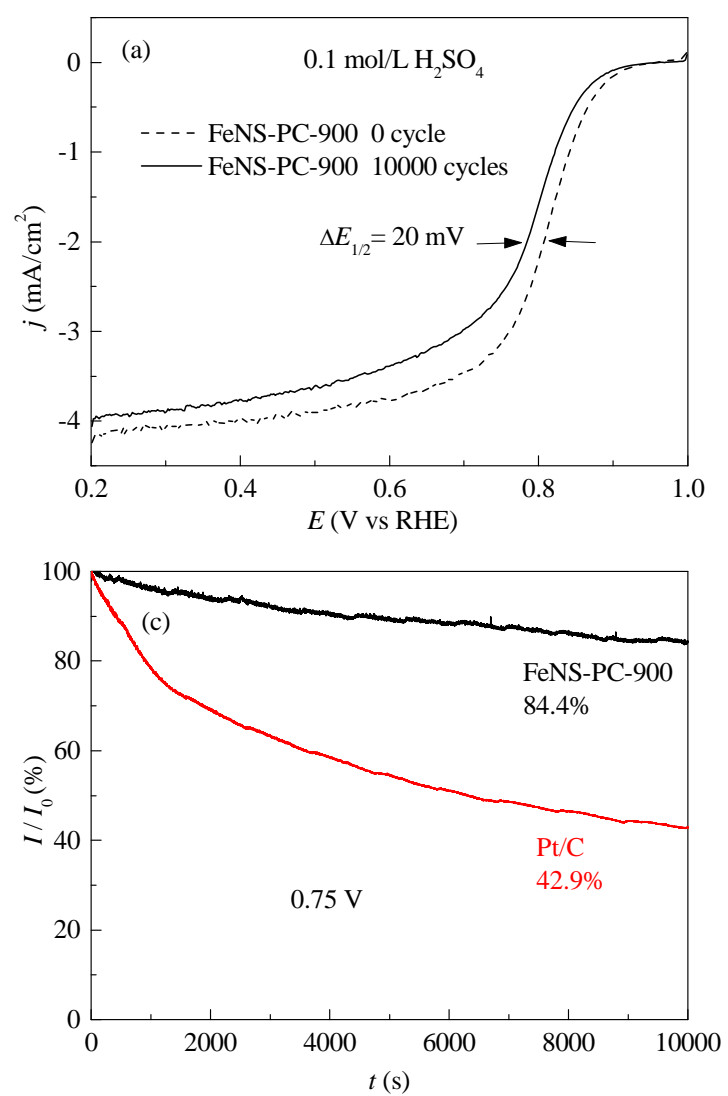

The durability of FeNS-PC-900 was further evaluated by chronoamperometry at $0.75 \mathrm{~V}$ in $\mathrm{O}_{2}$-saturated $0.1 \mathrm{~mol} / \mathrm{L} \mathrm{H}_{2} \mathrm{SO}_{4}$. The rotational speed was fixed at $900 \mathrm{r} / \mathrm{min}$. The same experiment was conducted with $\mathrm{Pt} / \mathrm{C}$, except the electrolyte was $\mathrm{O}_{2}$-saturated $0.1 \mathrm{~mol} / \mathrm{L} \mathrm{HClO}_{4}$. Fig. 6(c) shows that the ORR activity of FeNS-PC-900 decreased slowly and $84.4 \%$ of the initial current was maintained after $10000 \mathrm{~s}$ of an RDE test. In contrast, the ORR current of $\mathrm{Pt} / \mathrm{C}$ declined rapidly and only $42.9 \%$ of the initial activity was retained, probably because of the inhibiting effect of Pt-O species formed on the Pt surface at $0.75 \mathrm{~V}$. The same $E_{1 / 2}$ degradation and superior ORR activity retention compared with those of $\mathrm{Pt} / \mathrm{C}$ both demonstrate the excellent durability of FeNS-PC-900, which can be attributed to robust doping of heteroatoms into the porous carbon framework.

Catalytic selectivity is also important in practical fuel cell systems in the case of fuel crossover, e.g., of methanol. The methanol tolerances of FeNS-PC-900 and Pt/C were tested by injecting methanol into the electrolyte during chronoamperometric measurements (Fig. 6(d)). FeNS-PC-900 showed excellent methanol tolerance and the ORR current barely changed in the presence of methanol $(0.5 \mathrm{~mol} / \mathrm{L})$. In contrast, the $\mathrm{Pt} / \mathrm{C}$ catalyst clearly lacked methanol resistance. The ORR current was immediately converted to a methanol oxidation current when methanol was added. High methanol tolerance makes FeNS-PC-900 a promising catalyst for use in direct methanol fuel cells.
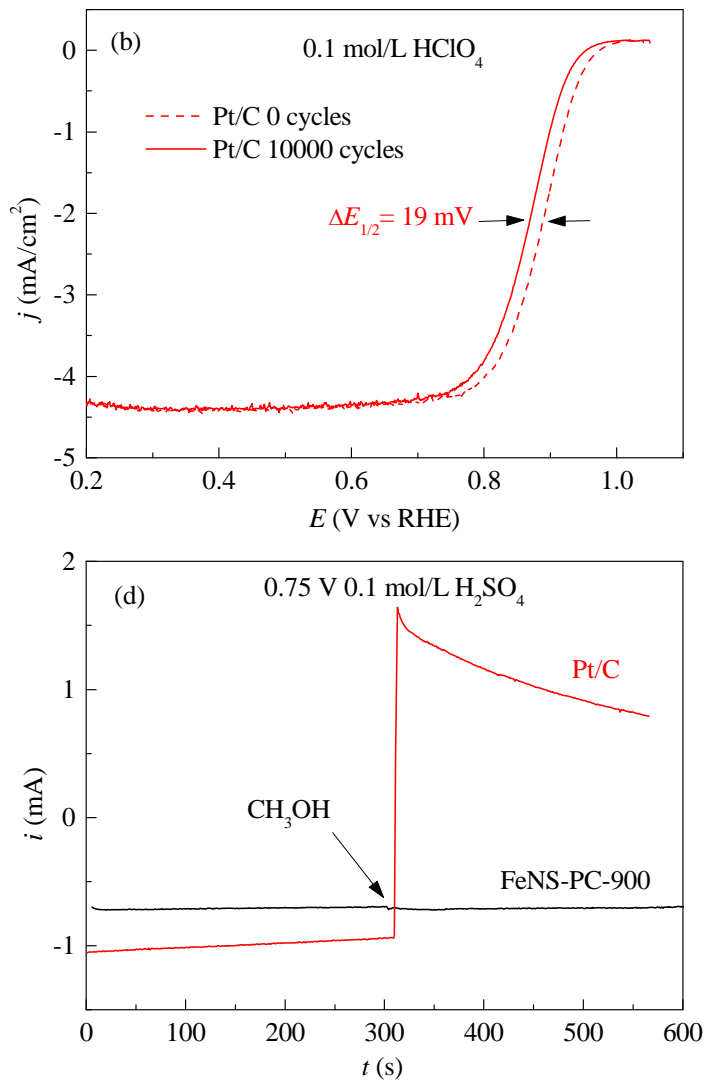

Fig. 6. ORR polarization curves of FeNS-PC-900 (a) and Pt/C (b) before and after 10000 potential cycles between $0.6-1.0 \mathrm{~V}$ at $50 \mathrm{mV} / \mathrm{s}$ in acidic medium; (c) chronoamperometric durability tests of FeNS-PC-900 and Pt/C catalysts at $0.75 \mathrm{~V}$; and (d) methanol tolerances of FeNS-PC-900 and Pt/C. Catalyst loadings were $0.6 \mathrm{mg} / \mathrm{cm}^{2}$ for FeNS-PC-900 and $0.1 \mathrm{mg} / \mathrm{cm}^{2}$ for Pt/C. Pt/C was tested in $\mathrm{HClO}_{4}$. 

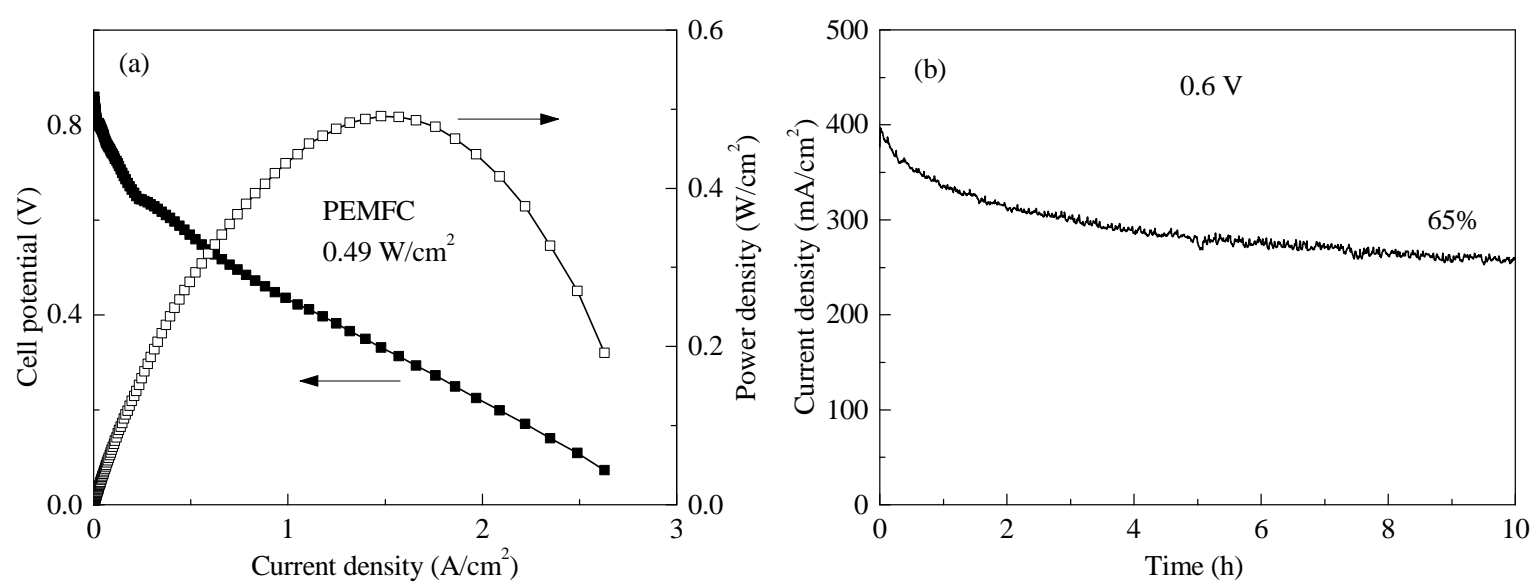

Fig. 7. Polarization and power density curves (a) and long-term durability test (b) of PEMFC using FeNS-PC-900 as the cathode catalyst and a Nafion 211 membrane.

Based on the high ORR activity and durability of FeNS-PC-900 in an acidic medium, we fabricated an MEA with FeNS-PC-900 (4 mg/cm $\left.{ }^{2}\right)$ as the cathode, Pt/C (40 wt\%, 0.4 $\mathrm{mgPt} / \mathrm{cm}^{2}$ ) as the anode, and a Nafion 211 membrane. The MEA was tested in a PEMFC system at $80^{\circ} \mathrm{C}$. Fig. 7(a) shows the polarization curve and power density plots of the PEMFC. The peak power density was $0.49 \mathrm{~W} / \mathrm{cm}^{2}$. The porous structure may facilitate the transport of ORR-relevant species and contribute to the high power density [27].

The long-term durability of PEMFCs using non-precious-metal catalysts, especially at high operating potentials $(>0.50 \mathrm{~V})$, is still a challenge. Fig. 7(b) shows that the current density of the fabricated fuel cell degraded slowly and $65 \%$ of the initial activity was maintained after operation for $10 \mathrm{~h}$ at a constant voltage of $0.6 \mathrm{~V}$. The current density of the PEMFC declined from 397 to $259 \mathrm{~mA} / \mathrm{cm}^{2}$. The performance degradation can be attributed to the decay of ORR active sites and partial water flooding of the catalyst layer.

\section{Conclusions}

We synthesized an excellent non-precious-metal ORR electrocatalyst based on Fe, N, S-doped porous carbon by carbonization of a mixture of MF resin and $\mathrm{Fe}(\mathrm{SCN})_{3}$, using $\mathrm{CaCl}_{2}$ as a template, at $900{ }^{\circ} \mathrm{C}$ (FeNS-PC-900). The $\mathrm{CaCl}_{2}$ was easily removed without using tedious and highly corrosive procedures. Simultaneous $\mathrm{Fe}, \mathrm{N}$ and S doping and porous carbon formation gave a uniform distribution of dopants. The mass activity of the FeNS-PC-900 catalyst was $10.2 \mathrm{~A} / \mathrm{g}$ at $0.8 \mathrm{~V}$ in an acidic medium. The durability and methanol resistance of FeNS-PC-900 were better than those of a state-of-the-art Pt/C catalyst. The FeNS-PC-900 catalyst also showed high activity in a PEMFC; a peak power density of $0.49 \mathrm{~W} / \mathrm{cm}^{2}$ and good long-term durability were achieved. The results show that FeNS-PC-900 is a promising alternative ORR catalyst for acid fuel cells.

\section{References}

[1] Y. Wang, K. S. Chen, J. Mishler, S. C. Cho, X. C. Adroher, Appl. Energy, 2011, 88, 981-1007.
[2] Y. Nie, L. Li, Z. D. Wei, Chem. Soc. Rev., 2015, 44, 2168-2201.

[3] Y. J. Wang, N. N. Zhao, B. Z. Fang, H. Li, X. T. Bi, H. J. Wang, Chem. Rev., 2015, 115, 3433-3467.

[4] F. Jaouen, E. Proietti, M. Lefèvre, R. Chenitz, J. P. Dodelet, G. Wu, H. T. Chung, C. M. Johnston, P. Zelenay, Energy Environ. Sci., 2011, 4, 114-130.

[5] M. H. Shao, Q. W. Chang, J. P. Dodelet, R. Chenitz, Chem. Rev., 2016, 116, 3594-3657.

[6] M. Lefèvre, E. Proietti, F. Jaouen, J. P. Dodelet, Science, 2009, 324, 71-74.

[7] G. Wu, K. L. More, C. M. Johnston, P. Zelenay, Science, 2011, 332, 443-447.

[8] E. Proietti, F. Jaouen, M. Lefèvre, N. Larouche, J. Tian, J. Herranz, J. P. Dodelet, Nat. Commun., 2011, 2, 416.

[9] Y. G. Li, W. Zhou, H. L. Wang, L. M. Xie, Y. Y. Liang, F. Wei, J. C. Idrobo, S. J. Pennycook, H. J. Dai, Nat. Nanotechnol., 2012, 7, 394-400.

[10] L. Z. Gu, L. H. Jiang, X. N. Li, J. T. Jin, J. H. Wang, G. Q. Sun, Chin. J. Catal., 2016, 37, 539-548.

[11] C. Chen, X. Zhang, Z. Y. Zhou, X. D. Yang, X. S. Zhang, S. G. Sun, Electrochim. Acta, 2016, 222, 1922-1930.

[12] Y. C. Wang, Y. J. Lai, L. Song, Z. Y. Zhou, J. G. Liu, Q. Wang, X. D. Yang, C. Chen, W. Shi, Y. P. Zheng, M. Rauf, S. G. Sun, Angew. Chem. Int. Ed., 2015, 54, 9907-9910.

[13] X. G. Su, J. G. Liu, Y. F. Yao, Y. You, X. Zhang, C. Y. Zhao, H. Wan, Y. Zhou, Z. G. Zou, Chem. Commun., 2015, 51, 16707-16709.

[14] J. Y. Cheon, T. Kim, Y. M. Choi, H. Y. Jeong, M. G. Kim, Y. J. Sa, J. Kim, Z. Lee, T. H. Yang, K. Kwon, O. Terasaki, G. G. Park, R. R. Adzic, S. H. Joo, Sci. Rep., 2013, 3, 2715.

[15] R. Silva, D. Voiry, M. Chhowalla, T. Asefa, J. Am. Chem. Soc., 2013, 135, 7823-7826.

[16] H. W. Liang, W. Wei, Z. S. Wu, X. L. Feng, K. Müllen, J. Am. Chem. Soc., 2013, 135, 16002-16005.

[17] W. Ding, L. Li, K. Xiong, Y. Wang, W. Li, Y. Nie, S. G. Chen, X. Q. Qi, Z. D. Wei, J. Am. Chem. Soc., 2015, 137, 5414-5420.

[18] G. W. Yang, H. Y. Han, T. T. Li, C. Y. Du, Carbon, 2012, 50, 3753-3765.

[19] D. Y. Zhai, H. D. Du, B. H. Li, Y. Zhu, F. Y. Kang, Carbon, 2011, 49, 725-729.

[20] J. J. Duan, S. Chen, M. Jaroniec, S. Z. Qiao, ACS Catal., 2015, 5, 5207-5234.

[21] L. F. Lai, J. R. Potts, D. Zhan, L. Wang, C. K. Poh, C. H. Tang, H. Gong, 


\title{
Graphical Abstract
}

Chin. J. Catal., 2017, 38: 673-682 doi: 10.1016/S1872-2067(17)62807-9

Fe, N, S-doped porous carbon as oxygen reduction reaction catalyst in acidic medium with high activity and durability synthesized using $\mathrm{CaCl}_{2}$ as template

Chi Chen, Zhiyou Zhou, Yucheng Wang, Xue Zhang, Xiaodong Yang, Xinsheng Zhang *, Shigang Sun * East China University of Science and Technology; Xiamen University

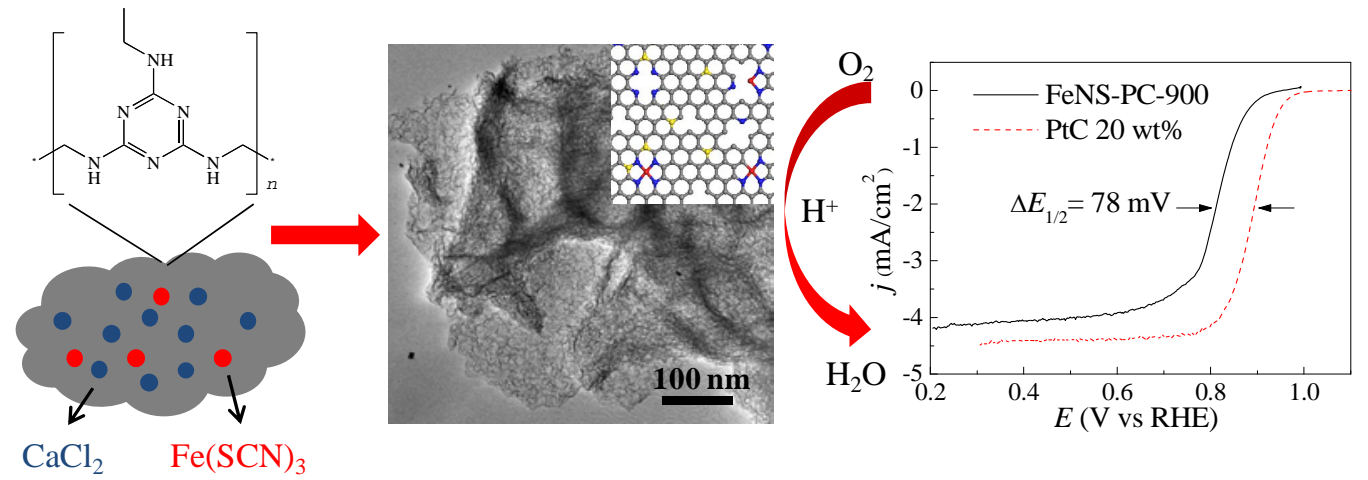

Fe, N, S-doped porous carbon was synthesized by direct carbonization of a mixture of melamine formaldehyde resin and $\mathrm{Fe}(\mathrm{SCN})_{3}$ using $\mathrm{CaCl}_{2}$ as a template. The porous carbon showed high activity and durability in the oxygen reduction reaction.

Z. X. Shen, J. Y. Lin, R. S. Ruoff, Energy Environ. Sci., 2012, 5, 7936-7942.

[22] W. Ai, Z. M. Luo, J. Jiang, J. H. Zhu, Z. Z. Du, Z. X. Fan, L. H. Xie, H. Zhang, W. Huang, T. Yu, Adv. Mater., 2014, 26, 6186-6192.

[23] C. Domínguez, F. J. Pérez-Alonso, S. A. Al-Thabaiti, S. N. Basahel, A. Y. Obaid, A. O. Alyoubi, J. L. Gómez de la Fuente, S. Rojas, Electrochim. Acta, 2015, 157, 158-165.

[24] X. J. Wang, H. G. Zhang, H. H. Lin, S. Gupta, C. Wang, Z. X. Tao, H. Fu,
T. Wang, J. Zheng, G. Wu, X. G. Li, Nano Energy, 2016, 25, 110-119.

[25] S. M. Zhang, B. Liu, S. L. Chen, Phys. Chem. Chem. Phys., 2013, 15, 18482-18490.

[26] C. Chen, X. D. Yang, Z. Y. Zhou, Y. J. Lai, M. Rauf, Y. Wang, J. Pan, L. Zhuang, Q. Wang, Y. C. Wang, N. Tian, X. S. Zhang, S. G. Sun, Chem. Commun., 2015, 51, 17092-17095.

[27] W. Shi, Y. C. Wang, C. Chen, X. D. Yang, Z. Y. Zhou, S. G. Sun, Chin. J. Catal., 2016, 37, 1103-1108.

\section{以 $\mathrm{CaCl}_{2}$ 为模板合成的高活性和高稳定性铁、氮、硫共掺杂多孔碳氧还原电催化剂}

\author{
陈 驰, ${ }^{\mathrm{a}, \mathrm{b}}$, 周志有 ${ }^{\mathrm{b}}$, 王宇成 ${ }^{\mathrm{b}}$, 张 雪 ${ }^{\mathrm{b}}$, 杨晓冬 ${ }^{\mathrm{b}}$, 张新胜, ${ }^{\mathrm{a},}$, 孙世刚 ${ }^{\mathrm{a}, \mathrm{b}}$,* \\ a华东理工大学化工学院, 化学工程联合国家重点实验室, 上海200237 \\ b厦门大学化学化工学院, 能源材料化学协同创新中心, 固体表面物理化学国家重点实验室, 福建厦门361005
}

摘要: 燃料电池是一种可将化学能通过电催化反应直接转化成电能的装置, 具有能量密度高和清洁无污染等优点. 燃料电 池阴极氧还原反应(ORR)的动力学较迟缓, 是电池能量效率损失的主要原因. 目前ORR催化活性最高的是铂基催化剂, 但由 于贵金属铂价格昂贵, 储量稀少, 且对燃料小分子渗透的抗性较差, 严重制约了燃料电池的大规模应用. 因此, 高性能、低成 本的非贵金属催化剂成为燃料电池领域的研究热点.

本文选用含氮量高达 $45 \%$ 的三聚氰胺-甲醛树脂为碳源和氮源, $\mathrm{Fe}(\mathrm{SCN})_{3}$ 为铁源和硫源, 以 $\mathrm{CaCl}_{2}$ 为模板, 在高温和铁的 催化作用下将树脂碳化, 经酸洗和二次热处理工艺, 制备出铁、氮、硫共掺杂的多孔碳(FeNS-PC). 干燥后的CaCl 2 颗粒可防 止树脂在高温下交联形成块状碳颗粒, 同时起到造孔模板的作用. $\mathrm{CaCl}_{2}$ 颗粒在温和条件下即可除去, 无需强腐蚀性条件, 因 此不会对催化活性中心造成破坏. 在Fe/N/C催化剂中掺杂 $S$ 可进一步提高催化活性, 不添加碳载体可避免低活性的碳载体 降低质量活性, 多孔结构可促进传质, 充分利用活性位点.

我们优化了热处理温度, 并对催化剂的结构、组分及催化性能等进行了表征分析. 结果表明, 热处理温度为 $900{ }^{\circ} \mathrm{C}$ 时, 可 将树脂完全转化成多孔碳, 并获得较高的杂原子掺杂量, 可达到最优活性. $\mathrm{CaCl}_{2}$ 为模板剂可避免使用强腐蚀性试剂去除模 板, 有利于保留活性位, 并得到多孔结构. FeNS-PC-900的比表面积可达 $775 \mathrm{~m}^{2} / \mathrm{g}$. 得益于原位掺杂的合成工艺, 各掺杂元素 在多孔碳表面均匀分布. 在酸性介质中, FeNS-PC-900的半波电位可达到 $0.811 \mathrm{~V}$, 仅比商业Pt/C催化剂低78 mV; 在0.8 V电位 下的质量活性为 $10.2 \mathrm{~A} / \mathrm{g}$, 表现出优异的催化活性. 经过 10000 圈加速衰减测试后, 其半波电位仅下降了 $20 \mathrm{mV}$, 在 $0.75 \mathrm{~V}$ 电位 下持续放电 $10000 \mathrm{~s}$ 后, 其ORR电流仍保持初始电流的 $84.4 \%$, 具有比Pt/C更加优异的稳定性. 以FeNS-PC-900为阴极催化剂 的质子交换膜燃料电池的最大功率密度可达到 $0.49 \mathrm{~W} / \mathrm{cm}^{2}$, 并在 $0.6 \mathrm{~V}$ 电压下持续放电 $10 \mathrm{~h}$ 后, 其电流仍可保持初始电流的 
$65 \%$, 表现出良好的应用潜力.

FeNS-PC-900具有高掺杂含量、高比表面积和多孔结构, 并且杂原子在催化剂表面均匀分散, 在半电池和燃料电池测试 中都表现出优异的催化活性和稳定性, 表明其是一种非常有潜力应用于燃料电池的非贵金属氧还原催化剂.

关键词: 非贵金属催化剂; 氧还原反应; 质子交换膜燃料电池; 铁、氮、硫共掺杂多孔碳; 三聚氰胺-甲醛树脂

收稿日期: 2017-02-17. 接受日期: 2017-03-07. 出版日期: 2017-04-05.

*通讯联系人. 电话: (0592)2180181; 电子信箱: sgsun@xmu.edu.cn

\#通讯联系人. 电话: (021)64253469; 电子信箱: xszhang@ecust.edu.cn

基金来源：国家重点基础研究发展计划(973计划, 2015CB932303); 国家自然科学基金(21373175, 21621091).

本文的英文电子版由Elsevier出版社在ScienceDirect上出版(http://www.sciencedirect.com/science/journal/18722067). 